\title{
INTERPRETING THE COUNCIL: ARCHBISHOP MANNING AND THE VATICAN DECREES CONTROVERSY
}

Jeffrey P. von Arx

Fairfield University, president@fairfield.edu

Follow this and additional works at: https://digitalcommons.fairfield.edu/history-facultypubs

Copyright 2002 Catholic Record Society http://www.catholicrecordsociety.co.uk

Recusant History http://www.catholicrecordsociety.co.uk/recusant-history

\section{Peer Reviewed}

\section{Repository Citation}

von Arx, Jeffrey P., "INTERPRETING THE COUNCIL: ARCHBISHOP MANNING AND THE VATICAN DECREES CONTROVERSY" (2002). History Faculty Publications. 35.

https://digitalcommons.fairfield.edu/history-facultypubs/35

\section{Published Citation}

von Arx S.J., Jeffrey P. "INTERPRETING THE COUNCIL: ARCHBISHOP MANNING AND THE VATICAN DECREES CONTROVERSY". Recusant History; May2002, Vol. 26 Issue 1, p229-242, 14p

This item has been accepted for inclusion in DigitalCommons@Fairfield by an authorized administrator of DigitalCommons@Fairfield. It is brought to you by DigitalCommons@Fairfield with permission from the rightsholder(s) and is protected by copyright and/or related rights. You are free to use this item in any way that is permitted by the copyright and related rights legislation that applies to your use. For other uses, you need to obtain permission from the rights-holder(s) directly, unless additional rights are indicated by a Creative Commons license in the record and/or on the work itself. For more information, please contact digitalcommons@fairfield.edu. 
${ }^{54}$ APASI, loc. cit., n. 9, Brown to Provincial, 6 April 1847. On St. Francis Xavier's College, see Contribution to Science and Technical Education in Late-Nineteenth-Century Liverpool', 'The Jesuil Science 43 (1986), pp. 353-68.

55 LRO, RCLV 5/1/461, Goss to Dean Gillow of Preston, 1 April 1857

56 APF, S.R. Anglia, vol. 21, nn. 588-603.

57 Edwards, pp. 202-3. See Decreta, pp. 345-65, for the full text of Romanos Pontifices.
58 Edwards, p. 202 .

\title{
?
}

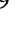

\section{INTERPRETING THE COUNCIL: ARCHBISHOP MANNING AND THE VATICAN DECREES CONTROVERSY}

\author{
by JefFrey PAUl von ArX, S.J.
}

Oontemporary Roman Catholics have realized in the last thirty-five years that when an ecumenical council has concluded, it is far from over. The interpretation of the decrees of the Second Vatican Council has become today as critical and controverted as the formulation of the decrees was during the Council itself. The present controversies centre on ecclesiology-the nature of the Church-and questions at issue concern continuity and innovation. Did Vatican II, and especially the Decree on the Church in the Modern World, reform the structure and the governance of the Church toward a greater degree of consultation, subsidiarity, decentralization-'collegiality', to use the expression of the Council itself? Or was the vision of the Council for the Church in basic continuity with the centralized, papal-monarchial Church of the First Vatican Council? Around these questions centres most of the contention that engages the Church today: debates having to do with the rôle of bishops' conferences, the operation of the Roman curia, the relationship of the magisterium or teaching authority to theologians.

Contemporary Catholic experience has taught us to look to the aftermath of a Council, therefore, to judge more amply of its significance and implications for the Church and for the Church's relation with society. Taking this lesson, we are not surprised to discover that the doctrine of papal infallibility became the focus of interpretive controversy after the First Vatican Council, both within and without the Church. What is less expected, is to discover that, in England at least, the focus of controversy over papal infallibility became the bearing of the doctrine on the civil allegiance of subjects; and the agent of that controversy none other than William Ewart Gladstone, recently resigned as prime minister.

There is already an adequate literature on the motivations of Gladstone in launching this controversy with the publication in November 1874 of his The Vatican Decrees in their Bearing on Civil Allegiance: A Political Expostulation.' Josef Altholz has argued that "Gladstone had become convinced that there actually was a "vast conspiracy" organized by the Roman Catholic hierarchy to direct a European war to the end of forcible restoration of the Pope's temporal power. He thought that the decrees of the Vatican Council on papal 
infallibility and obedience to the Pope could be used to compel Roman Catholics of Great Britain to employ their political powers in the interests of the Papacy. By denouncing the Vatican Decrees, Gladstone hoped to forestall this plan. ${ }^{2}$

It seems extraordinary to a later age that a man of Gladstone's intelligence and experience would actually believe that the leaders of the Catholic Church, especially in England, could contemplate, to say nothing of their being able to bring about, an European war in the interests of the Temporal Power. Altholz traces the genesis of this belief and it would be well to follow his argument in order to understand the first term of this debate.

Gladstone had long been interested, of course, in the process of Italian unification, in which the defence, and, after 1870, the restoration of the Temporal Power figured in the policy of some Roman Catholic leaders-the French clerical party being particularly active in this cause. And, Altholz points out, Gladstone himself had evidence of the power of the Roman Catholic hierarchy to influence the political actions of lay Catholics in the defeat of his Irish University Bill in 1873, the event which ultimately forced his recent resignation. But, says Altholz, "what may have been decisive in forming Gladstone's attitude was a letter from Döllinger which he received while engaged in writing his Expostulation. In this letter, Döllinger expressed his fears that the rumours of a new Franco-German war were "only too true.",3

Turning to the Expostulation itself, Altholz builds his argument that belief in a 'vast conspiracy' was, indeed, the primary motivation for Gladstone's decision to publish the tract. Gladstone discerned two purposes behind what he considered the novel and astonishing claims of the Council for the power of the Pope. These purposes corresponded to what Gladstone saw as the two principal effects of the decrees: the one theological-the proclamation of infallibility for the purpose of exploiting the vulnerability of weak minds to the assertion of authority - and the other political. The political significance of the decrees, Gladstone believed, was essentially a claim by the papacy on the civil allegiance of subjects. The consequence of this claim was the creation of political strife, now evident, for example in Germany. And it was 'a fixed purpose among the secret inspirers of Roman policy to pursue, by the road of force, upon the arrival of any favourable opportunity, the favourite project of re-erecting the terrestrial throne of the Popedom, even if it can only be re-erected on the ashes of the city, and amidst the whitening bones of its people. ${ }^{4}$

Gladstone did not believe that England itself had anything to fear from divided allegiance and Roman conspiracy so far as its own domestic tranquillity was concerned. But in light of Roman policy to restore the Temporal Power even at the cost of war, he considered that the existence of a strong ultramontane party in England, even though a minority, posed threats to European peace. The Roman Curia, he wrote, 'counts on the support in every country of an organised and devoted party; which, when it can command the scales of political power, will promote interference, and, when it is in a minority, will work for securing neutrality. As the peace of Europe may be in jeopardy, and as the duties even of England, as one (so to speak) of its constabulary authorities, might come to be in question, it would be most interesting to know the mental attitude of our Roman Catholic fellow-countrymen in England and Ireland with reference to the subject; and it seems to be one on which we are entitled to solicit information. ${ }^{5}$

Gladstone's Expostulation was, of course, the occasion for more than one response from English Roman Catholics. The most notable and lasting of these was John Henry Newman's Letter Addressed to His Grace the Duke of Norfolk on the Occasion of Mr. Gladstone's Recent Expostulation, which Newman wrote in December of 1874. Newman, as is widely recognized, took the opportunity of Gladstone's tract to explain his own position on infallibility and to distance himself from the more extreme ultramontane interpretations of the doctrine. ${ }^{6}$ As such, his Letter tended to address the issue raised by Gladstone of the first, or theological purpose of the decrees, especially the limits and extent of papal infallibility. Newman's views eventually found acceptance in Rome, and came to represent a kind of unofficial interpretation of the Council, at least in the English-speaking world. It is not widely known that this was in some part due to an intervention on his behalf with some of the more inflexible ultramontane curialists in Rome, who wanted to condemn him, by his sometime opponent, the formidable Archbishop of Westminster, Henry Edward Manning.

Newman's response, as effective as it was in interpreting the theological reach of the dogma of infallibility, addressed only indirectly the principal issue that Gladstone had raised in his Expostulation and his motivation for writing in the first place: the civil allegiance of English Roman Catholics, and what could be expected of them in the political arena. This latter issue was, however, precisely Manning's greatest concern as chief representative of the Roman Catholic communityboth in terms of the perception and reception of English Roman Catholics in the wider world of English politics, and in terms of engagement in politics on the part of the Catholic community itself. To suffer a direct attack on the legitimacy of Roman Catholic participation in politics, and this from the sometime leader of the party from whom Catholics had once received and from whom they still had reason to expect assistance, was ominous indeed, and must have raised for Manning the very fears that had so concerned him in relation to the Kulturkampf: that the State would move against religious bodies and deny them rights to political participation that they were able to exercise only on the condition of the forbearance of the state. ${ }^{8}$ This was already the reality in Germany, and Gladstone's Expostulation seemed to threaten that it might become a reality in England as well. 
Manning's identically entitled 'The Vatican Decrees in their Bearing on Civil Allegiance' appeared in February of 1875. The first thing Manning did in this response was-in sharp contrast to Newman-to dismiss the theological issue of papal infallibility from the debate. He chose to focus his attention in the tract instead on the issue of the civil allegiance of Roman Catholics and what he considered the injustice, indeed, the aggression of the civil power in seeking to impugn it.

In disposing of infallibility itself as an issue in the debate, Manning made two points. First, that the infallibility of the Church and the infallibility of the Pope within the Church were long-standing Catholic beliefs, and that the definition of the latter had not changed Catholic belief but only defined it. ${ }^{9}$ Therefore, in so far as the definitions of the Council affected the civil allegiance of Roman Catholics, it was the same after the Council as it was before. But in the above syllogism, Manning was not content to let the minor stand. The decrees of the Vatican Council did not affect the civil allegiance of Roman Catholics or the relation of the Church with the civil powers because in the decrees that were debated, voted on and promulgated, it did not intend so to do. ${ }^{10}$ There had, indeed, been a schema proposed on the Church's relation with the Civil State, but that schema was never even discussed in the Council. Of the two constitutions actually debated and promulgated, one dealt exclusively with matters of faith, and the other, the Dogmatic Constitution on the Church of Christ, dealt with the primacy, the jurisdiction and the infallibility of the Roman Pontiff, 'but it does not contain a syllable of the relation of the Primacy to the Civil or Political State, except to say that no human authority is needed for the validity of its acts, nor may any human power hinder their exercise'. ${ }^{11}$ The civil allegiance of Roman Catholics was, therefore, the same after the Council as it had been before, and that allegiance was not affected by the decrees of the Council in any significant way.

In his Expostulation, Gladstone had required, speaking presumably on behalf of Protestant Englishmen, an account of the civil allegiance of their Roman Catholic fellow subjects, and Manning had responded that civil allegiance was neither changed nor affected by the decrees of the Vatican Council. But Gladstone's challenge still left him confronting the need to vindicate the right of Roman Catholics to participate in political life against what Manning feared might be a campaign to exclude or limit that participation.

In order to prevent a campaign aimed at denying them their civil rights, Manning needed to show that the civil allegiance of Roman Catholics was not essentially different, certainly no worse, hopefully better, than the allegiance of other British subjects. And so, using a technique reminiscent of strategies he had adopted in 'Caesarism and Ultramontanism', ${ }^{12}$ he proposed to argue that 'the Civil Allegiance of Roman Catholics is as undivided as that of all Christians, and of all men who recognize a divine or natural moral law' ${ }^{13}$ This was to say in the first instance that the civil allegiance of Roman Catholics was not undivided, any more than the allegiance to the State of any religious or moral person was undivided. Every moral being recognized a dual authority as far as his or her civil allegiance was concerned: the authority of the State, and the authority of religion or the moral law. And every moral being, Manning believed, must admit that the authority of the Divine Law, or of conscience, was superior to the authority of the State and could justify setting the authority of the State aside.

Manning was willing to argue further: the civil allegiance of Roman Catholics was superior to the civil allegiance of non-Catholics and less likely to call the authority of the State into question for slight or transitory reasons. Protestants might defy the authority of the State on the basis of an ill-formed individual conscience; secularists according to the basis of an ill-formed individual conscience; secularists according the latest fad Roman Catholics, on the other hand, were guided in the formation of their political conscience by the whole of Christian morality, by the greatest system of ethical legislation the world has ever seen, the Canon Law and Moral Theology of the Catholic Church', and 'by an authority which the whole Christian world once believed to be the highest judicial tribunal and the source of civil order and stability'. ${ }^{14}$

But to say that the civil allegiance of Roman Catholics was prescribed by a system of ethical legislation in the Church and guaranteed by the authority of the Pope was perhaps not to give the comfort teed by the authority of the fought of the loyalty of Roman Catholics. For had not that same law and that same authority claimed the right to depose monarchs and to absolve subjects of their allegiance, and had not a pope actually done so in England before, in the case of Queen Elizabeth I? Gladstone had, in fact, raised the question of the deposing power in his Expostulation, wondering whether the assurances given by the Roman Catholic community at the time of Catholic Emancipation that the deposing power was obsolete beyond revival could still be trusted, and citing Manning himself to suggest that they could not. ${ }^{15}$ And, indeed, Manning was in a difficult position here. The teaching of the Church as regards the right relationship between the Church and the civil powers was, by his own admission, clear and long-standing, and did, in fact, include the deposing power, whose operation in the Middle Ages Manning was on record as approving. ${ }^{16,}$

Manning, however, had confronted before the problem of irreformable teaching that had been rendered irrelevant by the changed circumstances of the contemporary world. In the 1860 's, it will be recalled, he had worked his way from belief that the thesis position of official-and, of course, exclusive recognition-establishment, in English terms-was the only and best way for the Church to relate to the State, to the 
conviction that the Church was better off by far in the circumstance of a religiously neutral State and a democratic political order. ${ }^{17}$

Manning had come to this conclusion through a consideration of the process of secularization, what he had begun by calling the 'desecration' of the State. He had first advanced the notion of the desecration of the State in the early 1860 's, in connection with the destruction of the Temporal Power, in which context it had an almost entirely negative connotation. ${ }^{18}$ But in the course of that decade, Manning began to reflect on the significance of what he termed the 'moral disestablishment' of the Church of England. He gradually came to realize that within the context of an emerging mass democratic political order, it was precisely the religious neutrality of the State-to use a less loaded term for desecration - that freed religious bodies - the Catholic Church no less than the Anglican-for the most effective and least constrained pursuit of their spiritual mission. 19

In his response to Gladstone, Manning wanted to show first of all that English Roman Catholics repudiated the exercise of the deposing power and other such remnants of an extinct religious-political world order that would disqualify them for participation in modern English political life. But more positively, he wanted to encourage both the reception of English Roman Catholics by their fellow countrymen as equal participants in national political life, and the engagement of Roman Catholics themselves in this life.

Manning dealt with the difficult problem of repudiating the deposing power, without denying the validity of its exercise in the past, by appealing to a notion of the 'material and moral conditions' necessary for the exercise of spiritual authority in the temporal or political order. ${ }^{20}$ Basically, these material and moral conditions were the acceptance of the spiritual authority by the political culture in which it was exercised: i.e., the universal Catholic culture of Europe before the Reformation. Although this definition is circular, it enabled Manning to state categorically that the use of the deposing power in present day England 'would not be legitimate, or right, nor lawful', ${ }^{21}$ because those conditions were not present: 'the moral conditions which justified and demanded the deposition of tyrannical Princes, when the medieval world was both Christian and Catholic, have absolutely ceased to exist, now that the world has ceased to be Catholic, and has ceased to be even Christian. It has withdrawn itself socially as a whole, and in the public life of nations, from the unity and jurisdiction of the Christian Church. ${ }^{22}$ We recognize in the concept of a world which had withdrawn itself from the unity and jurisdiction of the Church another way of describing the 'desecrated' or secular political order that Manning had identified and then come to accept in the course of the 1860's.

Manning had wanted, however, to do more than offer assurances that Roman Catholics had abandoned opinions and policies that would disqualify them from public life. He wanted to claim for Roman
Catholics an affinity and commitment to the forms of democratic politics that were then emerging in England and elsewhere. In the context of this emerging politics, the claim was sometimes made that if Catholics were ever to become a majority in the population, they would use their power to compel others to conform to the Catholic faith. Manning denied this charge, and offered as evidence to the contrary first the recent example of Belgium, and second the record of the only instance in which Catholic Englishmen had succeeded in establishing a polity in which they were in control: the Maryland colony under Lord Baltimore. In the case of Belgium, the Catholic population had been in a vast majority at the creation of that country in 1830 . But it was a vast molic politicians who were responsible for drafting and passing the 'Four Liberties' that guaranteed freedom of religion to all subjects. ${ }^{23}$ In Maryland, even in an age when 'the old traditions of the Catholic Church were still vigorous in men's minds', the Catholics of Maryland guaranteed religious liberty to all Christians and invited non-Catholics to settle there. ${ }^{24}$ 'Such', Manning observes, 'was the Commonwealth founded by a Catholic upon the broad moral law I have here laid down-that faith is an act of the will, and to force men to profess what they do not believe is contrary to the law of God, and that to generate faith by force is morally impossible. ${ }^{.25}$

For Manning, the larger question raised first by the Kulturkampf and then by Gladstone's pamphlet was why the German government, and the statesman who had been until recently the leader of one of England's two great political parties, should call into question the civil allegiance of Roman Catholics, and then, in the one case act to deprive them of their civil rights, and in the other seem to be threatening so to do. For, it was Manning's contention that Catholics-at least English Catholics-were ready to accept the 'descecrated' or secular character of the liberal State as long as it was neutral and even-handed in its treatment of religious groups. They were eager to participate in democratic politics on an even playing field as one of a number of voluntary religious organizations. They did not seek advantage over other religious groups through special favours, but neither would they accept that their beliefs or the internal organization of their church should subject them to exceptive legislation.

From Manning's point of view, the civil allegiance of Catholics had come into question not because of any aggression on the Church's part, as Gladstone claimed, but rather because of a change of attitude on the part of states toward the Church that amounted to what he called an aggression of the civil power. If the Church had changed, it was to accept the new situation in which it found itself part of a secular political order. But states, having changed the rules, seemed now to wish to exclude the Church from participation in the very secular, democratic order they had imposed on it. 
Manning's evidence for the aggression of the civil power against the Church was drawn first from the history of the attempts of the European powers to intervene at the Vatican Council, and second, from the unfolding drama of the Kulturkampf. He had already told the story of the inspiration and dissemination of the circular sent by Prince Hohenlohe, the Bavarian foreign minister, to European powers in April of $1869 .^{26}$ In that document, Hohenlohe had informed the powers that the Vatican Council, which would be meeting in December, would almost certainly define the infallibility of the pope. He was concerned that the definition would have serious political repercussions for those powers with Catholic subjects. He suggested concerted action on the part of the powers to protest in advance any such decisions of the Council made without the concurrence of the powers. Once the Council had assembled in Rome, pressure was also brought to bear to prevent the definition of infallibility by a threat to withdraw the French troops who were protecting the city.

Five years after the Council, however, it was the Kulturkampf that gave Manning the greatest concern as a precedent for possible action of British politicians against the civil rights of Roman Catholic subjects. Manning had already had his say on this subject closer to the outbreak of the conflict, but by 1875 , more evidence was available that Manning believed shed important light on the motivation of the civil powers in their aggression against the Church.

One of the leading advisers to the German government in its ccclesiastical policy was Dr. Emil Friedberg, a liberal and a Protestant who was largely responsible for the drafting of the Falk laws. Friedberg had recently published a book entitled 'The German Empire and the Catholic Church.' Wilhelm von Ketteler, the bishop of Mainz, an inopportunist at the time of the Council who had, with all the other German bishops, subsequently accepted the Vatican decrees, had responded with a pamphlet, 'The New Prussian Bills on the Position of the Church in reference to the State.' von Ketteler asked himself the same question Manning had: what was the reason that the civil allegiance of Roman Catholics had been called into question, such that liberals like Friedberg could countenance laws against their civil and religious rights which were a denial of all that liberals stood for? 'The true reason of the thorough systematic change of the Liberal party', Ketteler had responded, 'as well as of all those measures aimed against the lawful rights of the Church is the spiritual power of the Church based on the foundation of freedom. ${ }^{27}$ By this von Ketteler meant that when the Church was free of state control, and could appeal to the people on a democratic franchise, it received significant support: 'Our crime as endangering the State', von Ketteler continues, 'consists in this-that wheresoever the people and the Church are free, the people turn to the Church, and not to the doctrines of the Liberal party.'28 And, of course, this was precisely the case in Germany where the Catholic Centre Party was one of the main parties in the Reichstag and more numerous than the National Liberals.

The electoral success of Catholics in the politics of the German Empire was, according to Ketteler, the reason that liberals like Friedburg now opposed the separation of Church and State that most liberals, in Germany and elsewhere, had long favoured. Ketteler quotes Friedburg as saying that "under actual circumstances, this [the separation of Church and State] would be a very injurious measure, for the Church has become too much united to the people., ${ }^{29}$ Ketteler's conclusion as he pondered the question of what had changed to bring about legislation against the Church was that it was the government that had changed its relations to the Church: 'not because the Catholic Church is changed its relations to the Church: 'not because the Catholic Church is becate the motives, though they are daily expressed in Parliament and in the Press by the Liberal party, to show that the Catholic Church must be robbed of her liberty, but because the German people must be torn away by force from the Church., ${ }^{30}$

Manning would be asked in the future to consider supporting a Catholic Party in England and Ireland on the model of the Centre Party in Germany, but would decline. ${ }^{31}$ Such a party was not part of his vision of how English and Irish Catholics should engage the political life of their country. But clearly Manning agreed with Ketteler's life of their country. But clearly Manning agreed with Ketteler's Roman Catholics. The Vatican Council was being used as a pretext for questioning the civil allegiance of Roman Catholics precisely at a time when Catholics were willing and eager to enter the mainstream of national political life. This was because supporters of the liberal state believed that the active participation of organized Roman Catholics in democratic politics was a threat to the non-sectarian character of the State. Manning argued not only that the inclusion of voluntary religious groups in political life was not injurious to the secular state, but that it was the very effort to exclude them that posed the real danger to the stability and survival of the liberal state.

English Roman Catholics recognized that the religious divisions of England required a state "secular in legislation and action. ${ }^{, 32}$ They, above all people, had no desire to return to a religious commonwealth. 'For nearly three centuries', Manning observed, 'we have been divided in politics because politics were mixed up with religion. Our Legislature teemed with penal laws such as the world had never seen, and that against half of the English population. ... But now for fifty years we have had peace, because we have common interests, and a solid common weal. .... And why? Because we have eliminated religious conflicts from our Legislation, because we have learned to be just. ... The late sudden and needless aggression on the Catholic religion is dangerous to the social and political tranquility of these Kingdoms. ${ }^{, 33}$ 
It is important to realize that when Manning uses the term 'secular', as he now begins to do, to describe what he had earlier referred to as the 'desecrated' State, he does not mean the same thing by it as would some secularists, then or today. He does not, for example, mean a civil polity free from the explicit influence of Christianity or opposed to the participation or recognition of religious groups as such in political and civil life. In the first place, England was still a Christian country, and Christianity persisted, in many ways, in the constitution and the laws of England, and Manning wished to assure his fellow countrymen that 'Catholics will never lend so much as a finger or a vote to overturn by political action the Christianity which still lingers in our public laws.' Indeed, they would cherish all of Christianity that remained in the public sphere, especially in popular education. In the second place, England was a 'mixed commonwealth' in which religious divisions were tolerable not because religious groups were blocked from access to public life - and public funds-but because there was an 'equitable balance for our manifold uses in the midst of our manifold divisions.' The secular state in Manning's definition was a place where 'no one has a right to control this mixed administration to satisfy his private conscience, or to claim to have it all his own way. ${ }^{, 34}$

It was essential, therefore, to the identity and ultimately to the stability of a secular State that it should be open to the involvement and participation of voluntary religious groups. To seek in any way to deny a religious community access to public life, or to call into question the fitness of members of such a community to participate in public life was to violate the first principle of secularism as Manning understood it, and to endanger the understandings that existed among all the groups that made up civil society in a 'mixed commonwealth'. Those understandings were not only among groups, as Manning had already indicated-that no one group should seek unfair advantage over the others by attempting to engross the administration or public funds in its interest-but also within a group. As we have seen, it had long been a great object of Manning's policy within the Catholic community to encourage the engagement and responsible participation of Roman Catholics in national politics. For an important politician like Gladstone to question the civil allegiance of Roman Catholics could obviously have a chilling effect on the political involvement of that community. But for six million Roman Catholics-and it is significant that Manning has here included the Irish - to hear and perhaps to internalize the message that there was an incompatibility between their religion and their loyalty was a danger not just to that community but to the stability of the State. ${ }^{35}$ Manning believed that Gladstone was playing with fire in trying to make Catholics choose between their religion and their loyalty: 'This is playing with edged tools, and in a matter where it is hardly moral to play at all. Great public disasters might be caused by the game, and the costs of the game would fall, not on the gamester, but upon innocent men, women and children., 36

Commentators have noticed that in contrast to earlier outbreaks of no-popery, such as, for example, the papal aggression affair of 18501851 attendant upon the re-establishment of the English Roman Catholic hierarchy, Gladstone's attack on the Vatican Council stirred little public controversy. ${ }^{37}$ Josef Altholz has gone so far as to say that the controversy 'marks the demise of no-popery as an overt issue in English politics. ${ }^{38}$ And it is true that for all his rhetoric, Gladstone rejected any notion of acting on the German example to limit the civil rights of Catholics, ${ }^{39}$ and Manning did not expect any such restrictions would be imposed. ${ }^{40}$ Indeed, Manning anticipated the judgment of later historians in his conviction that the controversy would be an opportunity for Catholics to gain a 'hearing . . . before the public justice of our country, ... [after which] we shall all understand each other better. Our civil and religious peace at home will be firmer by this trial. ${ }^{, 41}$

If the Vatican Decrees controversy is not another instance of nopopery of the classic kind, but rather represents the demise of the genre, it is, however, true that the controversy reveals an important difference of understanding between the leader of English Liberalism and the leader of England's Roman Catholics about the involvement of religious bodies in the liberal state. The question arises whether it was misunderstanding, or whether Gladstone and Manning had fundamentally opposed positions on the rôle of religious pluralism in the liberal state.

H.C.G. Matthew, co-editor of The Gladstone Diaries, has attempted to relate Gladstone's outburst over the Vatican decrees not only to the immediate domestic and international political circumstances that triggered it, but also to the development of Gladstone's thinking on churchstate relations over the course of his life. ${ }^{42}$ That theme was, of course, a preoccupation of Gladstone's, from the publication of his first book, The State in its Relations with the Church (1838), down to the Vatican decrees controversy. Matthew describes the central point of Gladstone's interest as 'institutional anglicanism: its relationship to nationality, and its compatibility, or incompatibility with a plural society'. ${ }^{43}$ Certainly in his youth, Gladstone had believed that Anglicanism and nationality were, or ought to be, coterminous, and justified the privileged and exclusive position of the Established Church. In the course of the 1840 's Gladstone had to admit that the expectations the Oxford movement had engendered - that the national church might become actually what it was ideally-were not to be realized. A situation of pluralism was inevitable, and would require the appropriate legislative recognition, not least to protect the Church of England from its critics.

But if national religion on exclusively Anglican terms was impossible, Matthew argues that Gladstone came to believe that 'perhaps pluralism could be accompanied by a general movement toward [a] vision of a reunited apostolic Christendom' ${ }^{44}$ As between the extremes of 
Protestantism and Romanism, Gladstone was convinced that this reunited apostolic Christianity would look very much like Anglicanism, so that if a movement toward ecumenism could be maintained, the vision of religious nationality in England might yet be realized. Matthew notes that there is here an essential ambivalence in Gladstone's thought between pluralism and religious nationalism. ${ }^{45}$ If Gladstone believed in religious pluralism, it was 'pluralism on anglican terms, a semi-plural solution, in which the national church conceded no more than necessary'. ${ }^{46}$ From this perspective, it is easy to see why it was that Gladstone was so injured and afflicted in the 1850 's by the defection from the Established Church of close friends like Manning. It is also easy to see why Gladstone would have been so very hostile to developments in the Roman Catholic Church represented by ultramontanism in general and the Vatican decrees in particular. The decrees were, in effect, a declaration on the part of the leadership of the Roman Catholic Church, one of the terms in Gladstone's equation of an ecumenical movement toward Anglicanism, that they were simply not interested in playing the rôle he had assigned them, but would define their identity as Church and their mission in politics and civil life according to their own perception of their needs. And Manning was in the unfortunate position of being both the local representative of this Church and one by whom Gladstone felt himself to have been personally betrayed.

In 1874-1875, Gladstone and Manning understood religious pluralism in the liberal state in essentially different ways. In the 1860 's, Manning had had to come to terms with the 'desecrated' or, as he came to call it increasingly in the course of this controversy, the 'secular' character of the liberal State. He accepted that the unity of a State based on religion was no more; that the 'common weal' now depended not on unity but on equity and fair dealing toward and among the manifold (religious) groups that made up civil society. And it was really the existence of pluralism in regard to religious conviction and affiliation that defined for Manning the 'liberalism' of the liberal State. All religious groups had to be free to be what they were within the limits of equity and fairness, and for Manning, the 'authenticity' of the liberal State (as opposed to its perversion in statism) consisted in its restraint: first in its resisting the temptation to set itself up as an arbitrary or artificial source of unity for civil society; second, in its willingness to permit and even to facilitate the self-expression of religious groups within the structure of politics not on sufferance but as part of its raison d'être.

Gladstone was at this stage still ambivalent about real religious pluralism, if by pluralism we understand accepting different religious bodies into the political nation for who and what they are, as long as they play by the rules and do not attempt to gain unfair advantage. As late as 1875 , Gladstone was still seeking a unity based on religious nationality and so was less able than Manning to come to terms with the consequences of real religious diversity. Matthew argues that with the Bulgarian atrocities agitation, Gladstone's vision of religious nationality underwent further development, becoming both more moralistic and consequently more secular ${ }^{47}$ But at the time of the Vatican Decrees controversy, it is difficult to avoid the conclusion that it was Henry Edward Manning who had the clearer understanding of how religious pluralism must work in an authentically liberal and non-sectarian State.

\section{NOTES}

See especially the articles of Josef L. Altholz: 'Gladstone and the Valican Decress', The Historian, 25 (May 1963), pp. 312-324; 'The Vatican Decrees Controversy', Catholic Historical Review, 57 (1972), pp. 593-605; 'Gladstone, Lord Ripon and the Vatican Deces, 1 Auti-Catholicism in Victoria 449-459; also the chapter 'Gladstone and Vaticanism', in E.R. Norman's Anicanism and the Question of England, (London (1968), pp. 81-104, H.C.G. Math. Biographical and Sociological Problems for the the East', in Derek Baker, ed., Religious Motvation. Blograrnstein, Protestant versus Catholic in Mid Chere A Question of Authority', in Peter Jagger, ed., Gladstone, Politics and Retigion (London, 1985); and Shane Leslie, Henry Edward Manning (London, 1921), pp. 244-248.

2 Althoiz, 'Gladstone and the Vatican Decrees', p. 324 .

tober $24,1874$.

in their Bearing on Civil Allegiance: A Political W.E. Gadstone, The Vatican Decrees in their Bearing on Civil Allon, 1875), p. lxi.

Expostulation', in Rome and ihe 'See for example, E.R. Norman, Anti-Catholicism in Victorian Engle 195-6.

Decrees Controversy 102.

102.
8 Se Jeffey P. von Arx, 'Archbishop Manning and the Kulturkampf', in Recusant History, Vol. 21, No
2 (October, 1992), p. 262.

${ }_{10}$ Manninging, The Vatic

"Ibidem, p. 30 .

p. i.e., not to argue from a Roman Catholic point of vid, Bulturkampf', p. 259

British Christians: see above, 'Archbishop 32.

it Manning, The Vatico

15 See Gladstone, Expostulation, pp. xxxvii and lxiii.

16 "The relations of the Catholic Church to the Civil Powers have been fixed immutably from the begining because they arise out of the Divine constitution of the Church and out of Civil Society natural order' (The Vatican Decrees ...., p. 43); on the deposing power, see p. 78 .

See von Arx, "Manning's ultramontanis
History, Vol. 19, No 3 (May, 1989), p. 342

18 lbidem, p. 335 .

Ibidem, p. 342.

The Vatican Decrees, p. 55

22 Vatcan Decrees, p. 8 .

23 lbidem, p. 91.

24 Ibidem, pp. 91-92.

${ }_{25}^{2}$ Ibidem, p. 92

${ }^{26}$ See Petri Privilegium, part III, (London, 1873). Manning believed that the German Catholic church historian and inopportunist Ignaz von Döllinger had been the inspiralion if not he author of intervene.

27 von Ketteler quoted in Manning, op. cit., p. 117.

28 von Ketteler quo

${ }^{29}$ Ketteler quoted in Manning, op. cit., p. 117

30 Ketteler, quoted in Manning, op cit., p. 120

${ }^{31}$ See von Arx, 'Catholics and Politics', in V.A. McClelland and M. Hodgetts, eds., From Without the Flaminian Gate (London, 1999), pp. 260-261.

${ }_{22}$ Manning. The Vatican Decrees ...., pp. 133-4. One of the earliest uses of the term 'secular' by Manning that I have been able to discover. 
33 Ibidem, pp. 135-6.

34 Ibidem, pp. $137-138$

35 Ibidem, pp. 138-9.

${ }^{36} \mathrm{Ibidem}$, p. 140

Altholz, 'The Vatican Decrees Controversy, 1874-1875', in Catholic Historical Review, vol. 57 (1972), pp. 593-605; E.R. Norman, chapter 4, 'Gladstone and Vaticanism', in his Anti-Catholicism in Victorian England (London,

'In the little that depends on me, I shall be guided hereafter, as heretofore, by the rule of mainshould not be changed by follies, the consequences of which, if the worst come to the worst, this country will have alike the power and, in case of need, the will to control.' Gladstone, 'The Vatican Decrees', pp. Ixxiv-v.

40 'But I have little fear that the stream of our equal legislation will be turned aside, much less turned back; or that our public peace will be broken. The destinies of the British Empire are in strong hands, guided by calm heads, and supported by a balanced and steady public opinion.' Manning, The Vatican ${ }_{41}$ thides. 140.

42 H.C.G. Pp. 178- 'Oladstone, Vaticanism, and the Question of the East', in D. Baker, ed., Religious Motivation: Biographical and Sociological problems for the Church Historian, pp. 417-442.

${ }^{43}$ Matthew, p. 418 .

${ }^{44}$ Ibidem, p. 420.

45 Ibidem, p. 428

Ibidem, p. 435 .

Vhidem, pp. 441-2.

\section{NOTES ON CONTRIBUTORS}

Peter Doyle is the author of Westminster Cathedral 1895-1995 and has contributed three volumes to the new Butler's Lives of the Saints. He is currently working on a history of the Archdiocese of Liverpool. (196 Castle Road, Bedford, MK40 3TY).

Francis Edwards, $\boldsymbol{S J}$, has written several books on Elizabethan and Jacobean themes, the latest of which, Plots and Plotters, is to be published shortly by Four Courts Press. (114 Mount Street, London, W1X 6AH).

John Finnis, $\boldsymbol{F B A}$, is professor of law in the University of Oxford and Vice-Master of University College (Oxford, OX1 4BH). He is also professor of law at the University of Notre Dame, Indiana and is assisting Patrick Martin, professor of law at Louisiana State University (Law Center, Louisiana State University, Baton Rouge, LA 70803 1000), in work towards completing a biography of William Sterrell.

Kenneth Hankins assistant archivist for the Diocese of Clifton, has made a special study of the rôle of the Jesuits in the Catholic Life of Bristol. He has written articles on the subject and a history of the Jesuits' former city-centre church, St. Mary-on-the-Quay. (4 Victoria Court, Durdham Park, Bristol, B56 6XS).

Michael Hodgetts is volumes editor for the CRS, the author of Secret Hiding-Places and of many articles on the theme. (68 Goldieslie Road, Sutton Coldfield, West Midlands, B73 5PG)

Geoffrey Holt, $\boldsymbol{S J}$, has written extensively on English Catholic history of the 17th, 18th and 19th centuries. His major publications are given in the dedication of this number of Recusant History. (114 Mount Street London, W1X 6AH).

Sr. M. Gregory Kirkus, IBVM, has recently published An IBVM Biographical Dictionary of the English Members and Major Benefactors (1667-2000). (The Bar Convent, York, YO24 1AQ).

Martin Murphy is the author of Blanco White: Self-Banished Spaniard and of St. Gregory's College, Seville 1592-1767. (38 Crawley Road, Witney, OX8 5HT).

Jeffrey Paul von Arx, SJ, is Dean of Fordham College in Fordham University and was associate professor of history at Georgetown University before assuming his position at Fordham in 1998. He is author of Progress and Pessimism, editor of Varieties of Ultramontanism and a sometime contributor to Recusant History. (Fordham University, Bronx, New York, 10458). 